\title{
Host erythrocyte polymorphisms and exposure to Plasmodium falciparum in Papua New Guinea
}

\author{
Freya JI Fowkes ${ }^{\dagger 1,2}$, Pascal Michon ${ }^{\dagger 1,7}$, Lynn Pilling1, Ruth M Ripley ${ }^{4}$, \\ Livingstone Tavul ${ }^{3}$, Heather J Imrie ${ }^{1}$, Caira M Woods ${ }^{2}$, Charles S Mgone ${ }^{5,9}$, \\ Adrian JF Luty6,8 and Karen P Day*1,2
}

\begin{abstract}
Address: ${ }^{1}$ The Peter Medawar Building for Pathogen Research, Department of Zoology, University of Oxford, UK, ${ }^{2}$ Department of Medical Parasitology, New York University School of Medicine, New York, USA, ${ }^{3}$ Papua New Guinea Institute of Medical Research, Madang, Papua New Guinea, ${ }^{4}$ Department of Statistics, University of Oxford, UK, ${ }^{5}$ African Malaria Network Trust, Dar es Salaam, Tanzania, ${ }^{6}$ Department of Parasitology, Institute for Tropical Medicine, University of Tübingen, Tübingen, Germany, ${ }^{7}$ PNG Institute of Medical Research, Madang, Papua New Guinea, ${ }^{8}$ Medical Parasitology, MMB-NCMLS, Radboud University Nijmegen Medical Centre, Nijmegen, The Netherlands and ${ }^{9} E u r o p e a n$ Developing Countries Clinical Trials Partnership, Tygerberg, Cape Town, South Africa

Email: Freya JI Fowkes - fowkes@wehi.edu.au; Pascal Michon - pmichon@datec.net.pg; Lynn Pilling - lynnpilling@hotmail.com; Ruth M Ripley - ruth@stats.ox.ac.uk; Livingstone Tavul - ltavul@pngimr.org.pg; Heather J Imrie - h.imrie@ntlworld.com; Caira M Woods - cmw364@med.nyu.edu; Charles S Mgone - mgone@edctp.org; Adrian JF Luty - a.luty@mmb.umcn.nl; Karen P Day* - karen.day@med.nyu.edu

* Corresponding author †Equal contributors
\end{abstract}

Published: 3 January 2008

Malaria Journal 2008, 7:1 doi:10.1186/1475-2875-7-1
Received: 19 April 2007

Accepted: 3 January 2008

This article is available from: http://www.malariajournal.com/content/7////

(C) 2008 Fowkes et al; licensee BioMed Central Ltd.

This is an Open Access article distributed under the terms of the Creative Commons Attribution License (http://creativecommons.org/licenses/by/2.0), which permits unrestricted use, distribution, and reproduction in any medium, provided the original work is properly cited.

\begin{abstract}
Background: The protection afforded by human erythrocyte polymorphisms against the malaria parasite, Plasmodium falciparum, has been proposed to be due to reduced ability of the parasite to invade or develop in erythrocytes. If this were the case, variable levels of parasitaemia and rates of seroconversion to infected-erythrocyte variant surface antigens (VSA) should be seen in different host genotypes.
\end{abstract}

Methods: To test this hypothesis, $P$. falciparum parasitaemia and anti-VSA antibody levels were measured in a cohort of 555 asymptomatic children from an area of intense malaria transmission in Papua New Guinea. Linear mixed models were used to investigate the effect of $\alpha^{+}$-thalassaemia, complement receptor-I and south-east Asian ovalocytosis, as well as glucose-6-phosphate dehydrogenase deficiency and $A B O$ blood group on parasitaemia and age-specific seroconversion to VSA.

Results: No host polymorphism showed a significant association with both parasite prevalence/ density and age-specific seroconversion to VSA.

Conclusion: Host erythrocyte polymorphisms commonly found in Papua New Guinea do not effect exposure to blood stage $P$. falciparum infection. This contrasts with data for sickle cell trait and highlights that the above-mentioned polymorphisms may confer protection against malaria via distinct mechanisms. 


\section{Background}

Human erythrocyte polymorphisms have long been thought to play a role in resistance to malaria. High frequencies of host erythrocyte polymorphisms such as $\alpha^{+}$thalassaemia, haemoglobin ( $\mathrm{Hb}) \mathrm{S}, \mathrm{Hb} \mathrm{C}, \mathrm{Hb}$ E, complement receptor-1 (CR1) deficiency, glucose-6-phosphate dehydrogenase (G6PD) deficiency and south-east Asian ovalocytosis (SAO) are found in malaria endemic areas. Case-control studies have demonstrated that these polymorphisms reduce the risk of severe falciparum malaria rather than mild malaria [1-22]. Experimentally, research has focused on examining the interactions between the parasite and the erythrocyte to try to understand possible mechanisms of protection of these polymorphisms. In vitro experiments have suggested reduced ability of Plasmodium falciparum to invade or sustain growth in abnormal erythrocytes [23]. Enhanced clearance of infected erythrocytes by phagocytosis, and increased enhanced susceptibility of $P$. falciparum-infected abnormal erythrocytes to oxidative stress, have also been proposed [24-28]. It has also been hypothesized that $\alpha^{+}$-thalassaemia, CR1 deficiency and blood group $\mathrm{O}$ may protect via reduced rosetting [5,21,29-32], the phenomenon whereby nonparasitized erythrocytes bind to parasitized erythrocytes.

It is well documented that individuals with sickle cell trait (HbAS) have lower parasite densities compared to HbAA individuals in asymptomatic, mild and severe malaria [18-20,33-44]. This, together with the observation that the time to reappearance of $P$. falciparum is lower in HbAS individuals after drug treatment [39], provides compelling evidence for a direct interaction of the parasite with the HbS containing erythrocytes or of improved immunity controlling the level of parasitaemia in those with sickle cell trait. However, data on other erythrocyte polymorphisms is less clear cut. Clinical studies have rarely demonstrated differences in parasite density among genotypes in symptomatic malaria. Epidemiological studies in asymptomatic individuals are inconsistent. Cross-sectional studies have shown that $\alpha^{+}$-thalassaemia $[45,46]$, SAO [47,48], G6PD [49-53] and ABO polymorphisms (no studies have examined CR1) have reduced parasite rates/densities while other studies provide no evidence of an effect of these polymorphisms on parasite densities [4,11,54-65]. Data from a single time point may not accurately represent exposure to infection and therefore results of these studies are hard to interpret.

There are two possible ways to measure exposure to malaria blood stage infection: 1) by comparing parasite prevalence/density and, 2) by comparing age-specific antibody seroconversion to major blood stage antigens among host genotypes. Seroconversion to P. falciparuminfected erythrocyte variant surface antigens (VSA), which include $P$. falciparum erythrocyte membrane protein-1
(PfEMP-1) and rifins, has been shown to be dependent on the intensity of transmission [66]. Antibody levels in endemic areas reflect the level of IgG seroconversion to $P$. falciparum-infected erythrocyte VSA [67]. Furthermore, a study in Tanzania showed that insecticide-treated bednets limited the repertoire of recognized VSA and reduced antibody levels [68]. Seroconversion can also be considered as a marker for the level of cumulative exposure to the parasite as it increases with age [69]. The more exposure to $P$. falciparum children receive in malaria-endemic areas, the younger children will seroconvert to VSA.

If human erythrocyte polymorphisms were to hamper invasion and/or growth of the parasite or enhance the antibody-dependent control of malarial infection, this should manifest as differences in both mean parasite densities and patterns of age-specific seroconversion to VSA. The frequency of the host polymorphisms $\alpha^{+}$-thalassaemia, CR1, ABO blood group, SAO and G6PD deficiency were determined in a group of children from Papua New Guinea (PNG). Parasitological criteria and levels of antiVSA antibodies were measured in these children in two consecutive surveys, one year apart. The relationship between these genetic polymorphisms, parasite prevalence/density and age-specific antibody seroconversion to VSA was investigated in a malaria endemic region of PNG.

\section{Methods \\ Study design and data collection}

Details of study design and data collection have been reported previously [54]. Briefly, a serial cross-sectional survey was conducted in asymptomatic children living in villages of the Amele region, Madang Province, PNG, where intense year-round malaria transmission occurs [70]. The study took place from November to December of 1999 and 2000 in 566 children aged $1-17$ years. A serial study design would ensure that any associations observed with host genotype would be less likely to have occurred by chance. Blood samples were collected using Vacutainer $^{\circledast}$ tubes (Becton Dickinson, UK) and EDTA as anti-coagulant. A small aliquot of whole blood was blotted onto Isocode ${ }^{\circledR}$ Stix (Schleicher \& Schuell GmbH, Dassel, Germany) following the manufacturer's instructions, for further human genetic analyses. The remaining blood was centrifuged and separated into plasma (stored at $80^{\circ} \mathrm{C}$ ), buffy coat and erythrocyte pellet, both stored in guanidine hydrochloride at $4^{\circ} \mathrm{C} .555$ paired samples were available for antibody determination.

\section{DNA polymorphism analysis}

$\alpha^{+}$-Thalassaemia genotype was determined by polymerase chain reaction [54]. SAO genotyping was conducted as described earlier [71] using human DNA from Isocode $e^{\circledast}$ Stix. G6PD deficiency was evaluated qualitatively (Sigma Diagnostics visual colourimetric assay) and ABO blood 
groups were determined using anti-A and anti-B antibodies from a kit (BIOSCOT, Edinburgh, Scotland). CR1 genotype was determined by polymerase chain reaction and restriction fragment length polymorphism digest with HindIII as previously described with modifications [5,72].

\section{Parasites}

P. falciparum isolate PNG/M 12, was collected from a child presenting with acute symptomatic malaria at an aid post in Madang, during a longitudinal cohort study from 1990/91 [73]. Erythrocytes were washed three times after buffy coat depletion in RPMI 1640 media buffered with 25 mM 4-(2-hydroxyethyl)-1-piperazineethanesulfonic acid (HEPES) and supplemented with $25 \mathrm{mM}$ sodium bicarbonate, $2 \mathrm{mM}$ L-glutamine, $300 \mathrm{mM}$ hypoxanthine and $10 \mu \mathrm{g} / \mathrm{ml}$ gentamicin (Gibco, UK) (RPMI-HEPES), and cryopreserved in liquid nitrogen for adaptation in Oxford. Parasites were cultured in vitro using the method of Trager and Jensen [74] with modifications [75]. Cells were grown in RPMI/HEPES supplemented with $10 \% \mathrm{AB}$ serum (from donors residing in a non-malarious area), in an atmosphere of $5 \% \mathrm{CO}_{2}, 2 \% \mathrm{O}_{2}$, and $93 \% \mathrm{~N}_{2}$, sub-cultured into $\mathrm{O}$ positive erythrocytes (Oxford Blood Transfusion Service, UK) and stabilates frozen down. Adaptation and maintenance of PfEMP-1 expressing lines were made following a previously published method [67].

\section{Surface Immunofluorescence Assay (SIFA)}

Detection of antibodies bound to the surface of infected erythrocytes (IE) have previously been described [67]. Briefly, trophozoites were synchronized and enriched by Plasmagel $^{\circledast}$ (Laboratoire Roger Bellon, France) flotation[76]. After washing $2 \times$ in RPMI and $1 \times$ with human tonicity phosphate-buffered saline (HTPBS)/1\% BSA (Sigma, UK), trophozoite-IE were adjusted to $10-15 \%$ parasitaemia. Fifty $\mu$ of $1 / 50$ dilution of plasma was added to $5 \mu$ packed cell volume of IE and incubated for 30 mins at RT. All washes between each step were done $3 \times$ with HTPBS/1\% Bovine serum albumin (BSA). The next antibody layer was a rabbit anti-human IgG (Dako, UK) (1/100 dilution). The final antibody layer was a $1 / 100$ dilution of FITC-coupled swine anti-rabbit IgG (Dako, UK) containing $50 \mu \mathrm{g} / \mathrm{ml}$ ethidium bromide. Cells were fixed for $1 \mathrm{~h}$ with $0.5 \%$ paraformaldehyde diluted in HTPBS/1\% BSA, then washed $1 \times$ and resuspended with HTPBS. Samples were read on a FACSCalibur ${ }^{\mathrm{TM}}$ flow cytometer (Becton Dickinson, UK): 1000 IE were counted using the program CELLQUEST ${ }^{\text {тм }} 3.3$ (Becton Dickinson, UK) for Macintosh. A hyper immune plasma (HIP) pool from 10 adult residents from Madang and normal human serum (NHS) from three non malaria-exposed Europeans (Oxford Blood Transfusion Service, UK) were used as positive and negative controls, respectively, as previously described [67]. The percentage of IE staining positive for human plasma was calculated relative to the response to HIP and NHS as described earlier [67].

\section{Statistical analysis}

Due to the repeated measures study design, appropriate statistical tests were chosen to analyze paired data. The association of host polymorphisms and P. falciparum presence in no surveys, one survey and two surveys was assessed by ordinal regression with adjustments for age. Differences in frequency of positive slides were assessed using $\chi^{2}$ tests for each study year. Linear mixed models were used to examine the variation of parasite density among host genotypes with adjustments for age. Linear mixed models were also used to investigate the effect of age, parasite density and genotype on antibody levels: the two values were treated as a repeated measure with a heterogeneous compound symmetry covariance structure. Since the antibody levels showed considerable heteroscedasticity, they were transformed before analysis, using the transformation $\log ($ antibody +2.5$)$. The $P$. falciparum counts were transformed by $\log (P$. falciparum +1$)$ to reduce skewness while leaving the zero values unchanged. The models examined the effect of $P$. falciparum (logarithm of density), age (continuous), and either $\alpha^{+}$-thalassaemia genotype, CR1 genotype, $\mathrm{ABO}$ blood group (four categories $[\mathrm{A}, \mathrm{B}, \mathrm{AB}, \mathrm{O}]$ and two categories $[\mathrm{O}$ and nonO]), SAO genotype or G6PD phenotype (three categories [normal, intermediate, deficient] and two categories [normal, abnormal]). Interactions between host erythrocyte polymorphisms were also examined but some subgroups obtained were too small for reliable analysis. An interaction between sex and G6PD deficiency was also examined as G6PD deficiency is an X-linked disorder [77]. CR1 expression has been shown to be associated with $\alpha^{+}$-thalassaemia genotype [5], therefore adjustments were made for the respective polymorphism in ordinal regression and mixed linear analysis. Addition of each polymorphism in each analysis did not alter the final result so no adjustments were made in the final models. The models were developed using R 1.8.1 [78] and SPSS (version 12.0) and variables with $\mathrm{p}$-values $<.05$ were considered significant.

Informed consent was obtained from subjects and their parents or guardians. The project received ethical approval from the PNG Medical Research Advisory Committee and Institutional Review Board of the New York University School of Medicine.

\section{Results}

\section{Characteristics of study cohort}

1,100 blood samples and thick smears were collected from 555 children aged 1-17 years (mean age $9.68 \pm$ 0.18 ) in the Amele region, Madang Province, PNG at two surveys in November-December of 1999 and 2000. Thirty-eight percent of samples were slide-positive for $P$. 
falciparum in both years of the study and $24.7 \%$ were positive for Plasmodium vivax. Only 57 samples (5.2\%) were positive for both $P$. falciparum and $P$. vivax. Geometric mean parasite density of $P$. falciparum was 680 parasites $/ \mu \mathrm{l}$ (95\% CI 567-814) and parasite density was negatively correlated with age $(\beta=-0.08$, standard error [SE] 0.02, $P=.002$ ).

Table 1 details the frequency of polymorphisms investigated in this study. High frequencies of $\alpha^{+}$-thalassaemia were found in this population $(92.9 \%)$ with a predominance of the 4.2 deletion allele (frequency $=0.71$ ). The CR1 L allele was also predominant with a prevalence of $94.6 \%$, whereas the host erythrocyte polymorphisms SAO and G6PD were relatively uncommon in this population $(<10 \%)$.

\section{Host polymorphisms and P. falciparum prevalence and density}

Table 1 also details whether a child was $P$. falciparum positive for one survey, two surveys or no surveys, according to host polymorphism. There was no association of $\alpha^{+}-$ thalassaemia $(P>.7)$, SAO $(P=.29)$ or G6PD deficiency $(P>.3)$ with $P$. falciparum prevalence either at both surveys, after adjustments for age. There was also no significant association of $\alpha^{+}$-thalassaemia $(P=.78)$, SAO $(P=.66)$ or G6PD deficiency $(P=.64)$ with mean parasite density, after adjustments for age. Children who were blood group B were less likely to be positive at both surveys compared to those who were blood group $\mathrm{O}(P=$ .005). When $P$. falciparum prevalence was analysed separately for each year, blood group B had a significantly lower prevalence of $P$. falciparum (27.8\%) compared to $\mathrm{O}$ $(43.3 \%)$ in 2000 only $(P=.02)$. There was no significant difference in mean parasite densities between $\mathrm{ABO}$ blood groups $(P \leq .4)$ as assessed by a mixed linear model, with adjustments for age. Children with the CR1 HL genotype were more likely to be $P$. falciparum positive for both surveys compared to $\mathrm{HH}$ individuals but this was of borderline significance $(P=.07)$. There was also weak evidence of CR1 HH genotype having lower geometric mean parasite densities (322 P. falciparum/ $\mu \mathrm{l}$, 95\%CI 129-807) compared to those who were HL (786 P. falciparum/ $\mu$, 95\% CI 584-1058, $P=.07$ ) or LL genotype (688 P. falciparum $/ \mu \mathrm{l}, 95 \%$ CI $540-876, P=.12$ ).

\section{Host polymorphisms and age-specific seroconversion to VSA}

A multivariate linear mixed model was used to examine the effect of age and parasitaemia on antibody levels

Table I: Host polymorphism and parasitological data for 555 children from the Amele region, Papua New Guinea

\begin{tabular}{|c|c|c|c|c|c|}
\hline \multirow[b]{2}{*}{ Host Polymorphism } & \multirow[b]{2}{*}{$\begin{array}{c}\text { Frequency } \\
\mathrm{n}(\%)\end{array}$} & \multicolumn{3}{|c|}{ P. falciparum Prevalence ${ }^{\mathrm{a}}$} & \multirow[b]{2}{*}{$P b$} \\
\hline & & $\begin{array}{c}\text { Negative } \\
\text { Both surveys } \\
n(\%)\end{array}$ & $\begin{array}{l}\text { Positive } \\
\text { One survey } \\
\text { n (\%) }\end{array}$ & $\begin{array}{c}\text { Positive } \\
\text { Both surveys } \\
n(\%)\end{array}$ & \\
\hline \multicolumn{6}{|l|}{$\alpha+$-Thalassaemia } \\
\hline$(\alpha \alpha / \alpha \alpha)$ & 39 (7.1) & $15(38.5)$ & $19(48.7)$ & $5(12.8)$ & . \\
\hline$(-\alpha / \alpha \alpha)$ & 205 (36.9) & $75(37.1)$ & $94(46.5)$ & $33(16.3)$ & 0.72 \\
\hline$(-\alpha /-\alpha)$ & $311(56.0)$ & $125(4 \mid .7)$ & $120(40.0)$ & $55(18.3)$ & 0.99 \\
\hline \multicolumn{6}{|l|}{ CRIC } \\
\hline $\mathrm{HH}$ & $29(5.4)$ & $14(48.3)$ & $12(4 \mid .4)$ & $3(10.3)$ & . \\
\hline $\mathrm{HL}$ & $188(35.5)$ & $70(38.0)$ & $78(42.4)$ & $36(19.6)$ & 0.07 \\
\hline LL & $313(59.1)$ & $121(39.9)$ & $133(43.9)$ & $49(16.2)$ & 0.11 \\
\hline \multicolumn{6}{|l|}{$A B O^{c}$} \\
\hline 0 & $180(32.6)$ & $69(39.4)$ & $66(37.7)$ & $40(22.9)$ & . \\
\hline non-O & $372(67.4)$ & $145(39.9)$ & $165(45.5)$ & $53(14.6)$ & 0.09 \\
\hline A & $178(32.2)$ & $62(35.6)$ & $80(46.0)$ & $32(18.4)$ & 0.83 \\
\hline B & $138(25.0)$ & $62(46.6)$ & $58(43.6)$ & $13(9.8)$ & 0.005 \\
\hline$A B$ & $56(10.1)$ & $21(37.5)$ & $27(48.2)$ & $8(14.3)$ & 0.27 \\
\hline \multicolumn{6}{|l|}{ SAOc } \\
\hline Normal & $506(91.2)$ & $200(40.4)$ & $211(42.6)$ & $84(17.0)$ & . \\
\hline SAO & $49(8.8)$ & $15(32.6)$ & $22(47.8)$ & $9(19.6)$ & 0.29 \\
\hline \multicolumn{6}{|l|}{ G6PDc } \\
\hline Normal & 477 (89.7) & $182(39.1)$ & 199 (42.7) & $85(18.2)$ & . \\
\hline Intermediate & $20(3.8)$ & $8(44.4)$ & $6(33.3)$ & $4(22.2)$ & 0.76 \\
\hline Deficient & $35(6.6)$ & $16(45.7)$ & $16(45.7)$ & $3(8.6)$ & 0.36 \\
\hline
\end{tabular}

a Missing data: 1999, $\mathrm{n}=1 ; 2000, \mathrm{n}=21$.

$b$ Differences in frequency of positive slides were assessed using ordinal regression with adjustments for age.

c Abbreviations: CRI, Complement receptor I; SAO, Southeast Asian Ovalocytosis; G6PD, Glucose-6-phosphate dehydrogenase deficiency. With the exception of SAO, these variables contain missing values. 
in samples from the cohort. Both age $(\beta=0.16$, SE 0.009, $P<.001)$ and parasitaemia $(\beta=0.03$, SE $0.007, P<.001)$ were found to positively influence antibody levels. This model was then applied to each of the five host erythrocyte polymorphisms investigated in this study. There was no significant difference in the age-dependent acquisition of VSA-specific antibodies with respect to ABO blood groups $(P \geq .39)$, SAO $(P=.39)$, or CR1 genotype $(P=$ .99). There was also no significant difference in agedependent seroconversion in children with G6PD deficiency $(P>.2)$, nor was there evidence of an interaction between G6PD deficiency and sex $(P=.16)$. There was an effect of $\alpha^{+}$-thalassaemia on age-dependent antiVSA antibody acquisition (Figure 1). Children who were heterozygous for $\alpha^{+}$-thalassaemia had a slower rate of antibody acquisition compared to children of normal genotype $(P=.02)$. There was no significant difference in rate of antibody acquisition between children of normal genotype and those that were homozygous for $\alpha^{+}$-thalassaemia $(P=.14)$.

\section{Discussion}

This study investigated age-specific antibody seroconversion in Amele villages on the north coast of PNG, where malaria transmission is intense [70]. The sample size of the study was sufficiently large to allow us to look for interactions among the most common polymorphisms.

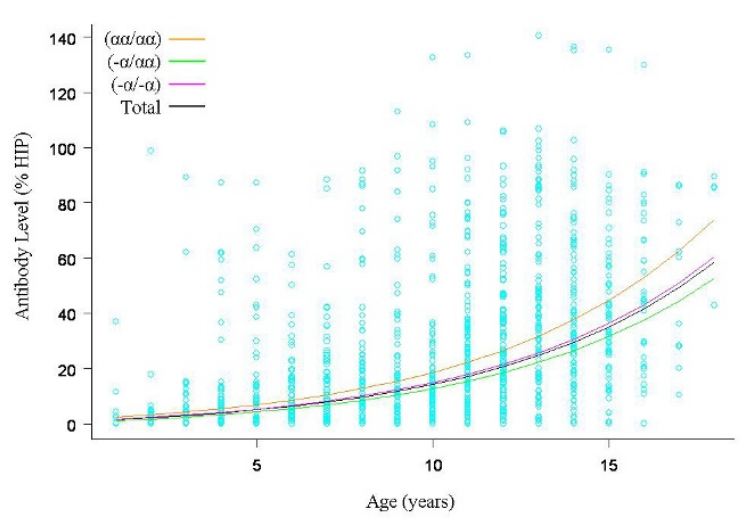

\section{Figure I}

Age-specific seroconversion to $P$. falciparum-infected erythrocyte variant surface antigens according to $\alpha^{+}$. thalassaemia genotype. Antibody levels are expressed as the percentage relative response to a hyper-immune plasma control (HIP). Data represent the predicted antibody levels from a mixed linear model including age, $P$. falciparum parasitaemia (with parasitaemia set to 0 ) and $\alpha^{+}$-thalassaemia genotype. There was statistical significance between children of normal genotype and children heterozygous for $\alpha^{+}$-thalassaemia only $(P=0.02)$.
Age was positively correlated with seroconversion to VSA, reflecting the association of age with exposure to malaria [66]. Parasitaemia was also positively correlated with VSA antibody levels. This result is similar to what has previously been shown in asymptomatic African populations to heterologous VSA [79]. It is therefore essential to make appropriate adjustments for age and parasitaemia when examining the association of host erythrocyte polymorphisms with age-specific antibody seroconversion.

Papua New Guinean children who are homozygous, but not heterozygous, for $\alpha^{+}$-thalassaemia are protected against severe malaria [1]. These children have significantly smaller erythrocytes compared to children of normal genotype, whereas erythrocyte parameters in heterozygotes are indistinguishable from normal individuals [80]. If there is a reduced physical interaction (i.e reduced invasion/growth, rosetting) or enhanced immune-mediated response between microcytic erythrocytes and $P$. falciparum, then a difference in parasite prevalence/density and seroconversion would be expected between homozygous children and those of normal genotype. This study showed there was no significant difference in age-specific seroconversion among these genotypes. Furthermore, there was no significant difference in $P$. falciparum density between $\alpha^{+}$-thalassaemia genotypes which is in concordance with other studies in children with asymptomatic parasitaemia [4,11,60-62]. There was some evidence of children of normal genotype having increased exposure compared to children who were heterozygous, but not homozygous, for $\alpha^{+}$-thalassaemia. This was surprising given that erythrocyte indices for heterozygotes are similar to children of normal genotype [80]. There is strong evidence that $\alpha^{+}$-thalassaemia confers particular protection against severe malarial anaemia. This must be independent of parasite density which has shown to be similar among $\alpha^{+}$-thalassaemia genotypes in children with acute malaria [1-4].

CR1 deficiency and blood group $\mathrm{O}$ are thought to protect against malaria by decreased rosetting. A positive correlation has been shown between rosetting and $P$. falciparum parasitaemia and it has been proposed that rosetting may enhance parasite survival by facilitating invasion and promoting immune evasion [81]. Polymorphisms associated with increased rosetting such as the CR1 $\mathrm{H}$ allele and AB blood antigens should lead to increased parasitaemia by this proposed mechanism. Contrary to this expectation, this study showed weak evidence of children with high levels of CR1 expression ( $\mathrm{HH}$ ) having lower $P$. falciparum prevalence and densities compared to children with lower CR1 expression (HL or LL genotype). This result could have occurred by chance given that only 15 children with $\mathrm{HH}$ were $P$. falciparum positive during the study. There was also evidence of blood group $\mathrm{B}$ having lower $P$. 
falciparum prevalence in the 2000 survey, but there was no significant difference in parasite densities among $\mathrm{ABO}$ blood groups. Neither ABO blood group and CR1 genotype had no effect on age-dependent seroconversion to anti-VSA antibodies, indicating that differences in parasitological data in these groups must have been due to chance. This study would support the hypothesis that $\mathrm{ABO}$ blood group and CR1 deficiency associated with the $\mathrm{L}$ allele protect against malaria by reduced rosetting and associated pathology rather than parasite density.

There was no significant difference in geometric mean parasite densities or rates of seroconversion to $P$. falciparum VSA with respect to G6PD and SAO genotypes. These data conflict with several studies that have proposed that innate resistance to malaria involved the inability for the malaria parasite to grow in and/or invade G6PD deficient and SAO erythrocytes [23]. There was also no evidence of an interaction between G6PD deficiency and sex with respect to anti-VSA seroconversion. A recent case-control study demonstrated that males, but not females, with G6PD deficiency were protected against severe malaria [12], but there was no significant difference in parasite density. Results presented here concur with this latter observation.

\section{Conclusion}

Data presented here highlight the importance of measuring malaria exposure at two time points to investigate the interactions of host polymorphisms with the malaria parasite. Results can occur by chance, and previous studies have reported data from a single time point. No polymorphism showed both a reduction in parasite prevalence/ density and age-specific seroconversion to anti-VSA antibodies. We interpret these findings to indicate that the mechanisms of protection by these polymorphisms are not fully explained by either structural aspects of the erythrocyte preventing infection or by enhanced immune responses to VSA. Our observations from PNG differ significantly from those we and others have seen for African children with HbAS and/or Hb C carriers. HbAS individuals have lower parasite prevalence/densities and delayed time to reinfection, as well as increased prevalence of antiVSA antibodies, compared to those of normal genotype $[18,24,36-39,44,82,83]$. Whereas HbC carriers exhibit no differences in parasite density, yet higher immune responses to VSA [83]. The enhanced immune reactivity in $\mathrm{Hb} S$ and $\mathrm{HbC}$ carriers would suggest that protection against malaria is partially mediated by acquired immunity. Conversely, the polymorphisms investigated in PNG may confer protection against the clinical pathologies of $P$. falciparum infection by a mechanism that does not influence parasite density or immunity to VSA.

\section{Authors' contributions}

FJIF performed data analysis, interpreted data and prepared the final manuscript with KPD. PM helped to draft the manuscript and undertook laboratory work (FACS assay and PCR-based host genotyping except CR1). LP and CMW helped undertake laboratory work and interpret data. HI and LT undertook laboratory and field work. RR participated in the design of analysis. CSM, AJFL and KPD conceived the study, participated in its design, and obtained funding for the project. All authors discussed the results and approved the final manuscript.

\section{Acknowledgements}

We thank all the Amele volunteers for their participation in the study and the staff from the Papua New Guinea Institute of Medical Research in Madang for their assistance in collecting and processing blood samples and for malaria microscopy readings. This investigation received financial support from the Wellcome Trust (Programme grant No 041354) and the European Union INCO Programme (contract no. ICI8-CT98-0359). The authors have no conflicts of interest.

\section{References}

I. Allen SJ, O'Donnell A, Alexander ND, Alpers MP, Peto TE, Clegg JB, Weatherall DJ: alpha+-Thalassemia protects children against disease caused by other infections as well as malaria. Proc Natl Acad Sci USA 1997, 94:|4736-|474I.

2. Mockenhaupt FP, Ehrhardt S, Gellert S, Otchwemah RN, Dietz E, Anemana SD, Bienzle U: alpha+-Thalassemia protects African children from severe malaria. Blood 2004, 1 04:2003-2006.

3. Williams TN, Wambua S, Uyoga S, Macharia A, Mwacharo JK, Newton $C R$, Maitland $K$ : Both heterozygous and homozygous alpha+ thalassemias protect against severe and fatal Plasmodium falciparum malaria on the coast of Kenya. Blood 2005, 106:368-37I.

4. Wambua S, Mwangi TW, Kortok M, Uyoga SM, Macharia AW, Mwacharo JK, Weatherall DJ, Snow RW, Marsh K, Williams TN: The effect of alpha(+)-thalassaemia on the incidence of malaria and other diseases in children living on the coast of Kenya. PLoS Med 2006, 3:e I58.

5. Cockburn IA, Mackinnon MJ, O'Donnell A, Allen SJ, Moulds JM, Baisor $M$, Bockarie $M$, Reeder JC, Rowe JA: A human complement receptor I polymorphism that reduces Plasmodium falciparum rosetting confers protection against severe malaria. Proc Natl Acad Sci USA 2004, I 0 I:272-277.

6. Ruwende C, Khoo SC, Snow RW, Yates SN, Kwiatkowski D, Gupta S, Warn P, Allsopp CE, Gilbert SC, Peschu N, Newbold CI, Greenwood BM, Marsh K, Hill AVS: Natural selection of hemi- and heterozygotes for G6PD deficiency in Africa by resistance to severe malaria. Nature 1995, 376:246-249.

7. Allen SJ, O'Donnell A, Alexander ND, Mgone CS, Peto TE, Clegg JB, Alpers MP, Weatherall DJ: Prevention of cerebral malaria in children in Papua New Guinea by southeast Asian ovalocytosis band 3. Am J Trop Med Hyg 1999, 60:1056-1060.

8. Genton B, al-Yaman F, Mgone CS, Alexander N, Paniu MM, Alpers MP, Mokela D: Ovalocytosis and cerebral malaria [letter]. Nature 1995, 378:564-565.

9. Fischer PR, Boone P: Short report: severe malaria associated with blood group. Am J Trop Med Hyg 1998, 58: I22-I23.

10. Lell B, May J, Schmidt-Ott RJ, Lehman LG, Luckner D, Greve B, Matousek P, Schmid D, Herbich K, Mockenhaupt FP, Meyer CG, Bienzle $U$, Kremsner PG: The role of red blood cell polymorphisms in resistance and susceptibility to malaria. Clin Infect Dis 1999, 28:794-799.

II. Williams TN, Mwangi TW, Wambua S, Peto TE, Weatherall DJ, Gupta S, Recker M, Penman BS, Uyoga S, Macharia A, Mwacharo JK, Snow RW, Marsh K: Negative epistasis between the malariaprotective effects of alpha(+)-thalassemia and the sickle cell trait. Nat Genet 2005, 37: I253-I 257. 
12. Guindo A, Fairhurst RM, Doumbo OK, Wellems TE, Diallo DA: $\mathbf{X}$ Linked G6PD deficiency protects hemizygous males but not heterozygous females against severe malaria. PLoS Med 2007, 4:e66.

13. Agarwal A, Guindo A, Cissoko Y, Taylor JG, Coulibaly D, Kone A, Kayentao K, Djimde A, Plowe CV, Doumbo O, Wellems TE, Diallo $D$ : Hemoglobin $C$ associated with protection from severe malaria in the Dogon of Mali, a West African population with a low prevalence of hemoglobin S. Blood 2000, 96:2358-2363.

14. Mockenhaupt FP, Ehrhardt S, Cramer JP, Otchwemah RN, Anemana SD, Goltz K, Mylius F, Dietz E, Eggelte TA, Bienzle U: Hemoglobin $C$ and resistance to severe malaria in Ghanaian children. J Infect Dis 2004, 190:1006-1009.

15. Modiano D, Luoni G, Sirima BS, Simpore J, Verra F, Konate A, Rastrelli E, Olivieri A, Calissano C, Paganotti GM, D'Urbano L, Sanou I, Sawadogo A, Modiano G, Coluzzi M: Haemoglobin C protects against clinical Plasmodium falciparum malaria. Nature 200 I, 4 | 4:305-308.

16. Hutagalung $R$, Wilairatana $P$, Looareesuwan S, Brittenham GM, Aikawa M, Gordeuk VR: Influence of hemoglobin $E$ trait on the severity of Falciparum malaria. J Infect Dis 1999, I 79:283-286.

17. Chotivanich K, Udomsangpetch R, Pattanapanyasat K, Chierakul W, Simpson J, Looareesuwan S, White N: Hemoglobin E: a balanced polymorphism protective against high parasitemias and thus severe $\boldsymbol{P}$ falciparum malaria. Blood 2002, I 00: I I 72-I I 76.

18. Aidoo M, Terlouw DJ, Kolczak MS, McElroy PD, ter Kuile FO, Kariuki $S$, Nahlen BL, Lal AA, Udhayakumar V: Protective effects of the sickle cell gene against malaria morbidity and mortality. Lancet 2002, 359:13||-1312.

19. Williams TN, Mwangi TW, Roberts DJ, Alexander ND, Weatherall DJ, Wambua S, Kortok M, Snow RW, Marsh K: An Immune Basis for Malaria Protection by the Sickle Cell Trait. PLoS Med 2005, 2:el28.

20. Williams TN, Mwangi TW, Wambua S, Alexander ND, Kortok M, Snow RW, Marsh K: Sickle Cell Trait and the Risk of Plasmodium falciparum Malaria and Other Childhood Diseases. J Infect Dis 2005, 192: I78-186.

21. Rowe JA, Handel IG, Thera MA, Deans AM, Lyke KE, Kone A, Diallo DA, Raza A, Kai O, Marsh K, Plowe CV, Doumbo OK, Moulds JM Blood group $O$ protects against severe Plasmodium falciparum malaria through the mechanism of reduced rosetting. Proc Natl Acad Sci USA 2007, 104: I 747I- I7476.

22. May J, Evans JA, Timmann C, Ehmen C, Busch W, Thye T, Agbenyega $T$, Horstmann RD: Hemoglobin variants and disease manifestations in severe falciparum malaria. JAMA 2007 297:2220-2226.

23. Williams TN: Red blood cell defects and malaria. Mol Biochem Parasitol 2006, I49:121-127.

24. Ayi K, Turrini F, Piga A, Arese P: Enhanced phagocytosis of ringparasitized mutant erythrocytes. A common mechanism that may explain protection against falciparum-malaria in sickle-trait and beta-thalassemia-trait. Blood 2004, 1 04:3364-337I.

25. Giribaldi G, Ulliers D, Mannu F, Arese P, Turrini F: Growth of Plasmodium falciparum induces stage-dependent haemichrome formation, oxidative aggregation of band 3, membrane deposition of complement and antibodies, and phagocytosis of parasitized erythrocytes. Br J Haematol 200 I, I I 3:492-499.

26. Cappadoro M, Giribaldi G, O'Brien E, Turrini F, Mannu F, Ulliers D, Simula G, Luzzatto L, Arese P: Early phagocytosis of glucose-6phosphate dehydrogenase (G6PD)-deficient erythrocytes parasitized by Plasmodium falciparum may explain malaria protection in G6PD deficiency. Blood 1998, 92:2527-2534.

27. Destro-Bisol G, D'Aloja E, Spedini G, Scatena R, Giardina B, Pascali V: Brief communication: Resistance to Falciparum malaria in alpha-thalassemia, oxidative stress, and hemoglobin oxidation. Am J Phys Anthropol 1999, 109:269-273.

28. Luzzi GA, Merry AH, Newbold Cl, Marsh K, Pasvol G: Protection by alpha-thalassaemia against Plasmodium falciparum malaria: modified surface antigen expression rather than impaired growth or cytoadherence. Immunol Lett 1991, 30:233-240.

29. Stoute JA: Complement-regulatory proteins in severe malaria: too little or too much of a good thing? Trends Parasitol 2005, 2 I:2 18-223.
30. Rowe A, Obeiro J, Newbold Cl, Marsh K: Plasmodium falciparum rosetting is associated with malaria severity in Kenya. Infect Immun 1995, 63:2323-2326.

31. Udomsangpetch R, Todd J, Carlson J, Greenwood BM: The effects of hemoglobin genotype and $A B O$ blood group on the formation of rosettes by Plasmodium falciparum-infected red blood cells. Am J Trop Med Hyg 1993, 48: I49-I 53.

32. Carlson J, Nash GB, Gabutti V, al-Yaman F, Wahlgren M: Natural protection against severe Plasmodium falciparum malaria due to impaired rosette formation. Blood I994, 84:3909-39|4.

33. Allison AC: Protection afforded by sickle-cell trait against subtertian malareal infection. Br Med J 1954, I (4857):290-4.

34. Hill AV, Allsopp CE, Kwiatkowski D, Anstey NM, Twumasi P, Rowe PA, Bennett S, Brewster D, McMichael AJ, Greenwood BM: Common west African HLA antigens are associated with protection from severe malaria. Nature 1991, 352:595-600.

35. Allen SJ, Rowe P, Allsopp CE, Riley EM, Jakobsen PH, Hill AV, Greenwood BM: A prospective study of the influence of alpha thalassaemia on morbidity from malaria and immune responses to defined Plasmodium falciparum antigens in Gambian children. Trans R Soc Trop Med Hyg 1993, 87:282-285.

36. Aluoch JR: Higher resistance to Plasmodium falciparum infection in patients with homozygous sickle cell disease in western Kenya. Trop Med Int Health I997, 2:568-57I.

37. Le Hesran JY, Personne I, Personne P, Fievet N, Dubois B, Beyeme M, Boudin C, Cot M, Deloron P: Longitudinal study of Plasmodium falciparum infection and immune responses in infants with or without the sickle cell trait. Int J Epidemiol I999, 28:793-798.

38. Marsh K, Otoo L, Hayes RJ, Carson DC, Greenwood BM: Antibodies to blood stage antigens of Plasmodium falciparum in rural Gambians and their relation to protection against infection. Trans R Soc Trop Med Hyg 1989, 83:293-303.

39. Sokhna CS, Rogier C, Dieye A, Trape JF: Host factors affecting the delay of reappearance of Plasmodium falciparum after radical treatment among a semi-immune population exposed to intense perennial transmission. Am J Trop Med Hyg 2000, 62:266-270.

40. Ackerman H, Usen S, Jallow M, Sisay-Joof F, Pinder M, Kwiatkowski DP: A comparison of case-control and family-based association methods: the example of sickle-cell and malaria. Ann Hum Genet 2005, 69:559-565.

41. Missinou MA, Lell B, Kremsner PG: Uncommon asymptomatic Plasmodium falciparum infections in Gabonese children. Clin Infect Dis 2003, 36: I 198-1202.

42. Fleming AF, Storey J, Molineaux L, Iroko EA, Attai ED: Abnormal haemoglobins in the Sudan savanna of Nigeria. I. Prevalence of haemoglobins and relationships between sickle cell trait, malaria and survival. Ann Trop Med Parasitol 1979, 73:|6|-I72.

43. Gendrel D, Kombila M, Nardou M, Gendrel C, Djouba F, RichardLenoble D: Protection against Plasmodium falciparum infection in children with hemoglobin S. Pediatr Infect Dis J 1991, I 0:620-62I.

44. Allen SJ, Bennett S, Riley EM, Rowe PA, Jakobsen PH, O'Donnell A, Greenwood BM: Morbidity from malaria and immune responses to defined Plasmodium falciparum antigens in children with sickle cell trait in The Gambia. Trans $R$ Soc Trop Med Hyg 1992, 86:494-498.

45. Oppenheimer SJ, Higgs DR, Weatherall DJ, Barker J, Spark RA: Alpha thalassaemia in Papua New Guinea. Lancet 1984, I:424-426.

46. Enevold A, Alifrangis M, Sanchez JJ, Carneiro I, Roper C, Borsting C, Lusingu J, Vestergaard LS, Lemnge MM, Morling N, riley E, Drakely C): Associations between alpha+-thalassemia and Plasmodium falciparum malarial infection in northeastern Tanzania. Journal of Infectious Diseases 2007, I 96:45 I-459.

47. Cattani JA, Gibson FD, Alpers MP, Crane GG: Hereditary ovalocytosis and reduced susceptibility to malaria in Papua New Guinea. Trans R Soc Trop Med Hyg 1987, 8 I (5):705-9.

48. Foo LC, Rekhraj V, Chiang GL, Mak JW: Ovalocytosis protects against severe malaria parasitemia in the Malayan aborigines. Am J Trop Med Hyg 1992, 47:27I-275.

49. Domarle O, Migot-Nabias F, Mvoukani JL, Lu CY, Nabias R, Mayombo J, Tiga $H$, Deloron P: Factors influencing resistance to reinfection with Plasmodium falciparum. Am J Trop Med Hyg 1999, 6I:926-93I.

50. Moyano M, Mendez F: [Erythrocyte defects and parasitemia density in patients with Plasmodium falciparum malaria in 
Buenaventura, Colombia]. Rev Panam Salud Publica 2005, I 8:25-32.

5I. Parikh S, Dorsey G, Rosenthal PJ: Host polymorphisms and the incidence of malaria in Ugandan children. Am J Trop Med Hyg 2004, 71:750-753.

52. Mombo LE, Ntoumi F, Bisseye C, Ossari S, Lu CY, Nagel RL, Krishnamoorthy R: Human genetic polymorphisms and asymptomatic Plasmodium falciparum malaria in Gabonese schoolchildren. Am J Trop Med Hyg 2003, 68: 186-190.

53. Oo M, Tin S, Marlar T, O'Sullivan W]: Genetic red cell disorders and severity of falciparum malaria in Myanmar. Bull World Health Organ 1995, 73:659-665.

54. Imrie H, Fowkes FJ, Michon P, Tavul L, Hume JC, Piper KP, Reeder JC, Day KP: Haptoglobin levels are associated with haptoglobin genotype and \{alpha\}+-thalassemia in a malaria-endemic area. Am J Trop Med Hyg 2006, 74:965-97I.

55. Montoya F, Restrepo M, Montoya AE, Rojas W: Blood groups and malaria. Rev Inst Med Trop Sao Paulo 1994, 36:33-38.

56. Shimizu H, Tamam M, Soemantri A, Ishida T: Glucose-6-phosphate dehydrogenase deficiency and Southeast Asian ovalocytosis in asymptomatic Plasmodium carriers in Sumba island, Indonesia. J Hum Genet 2005, 50:420-424.

57. Patel SS, King CL, Mgone CS, Kazura JW, Zimmerman PA: Glycophorin $C$ (Gerbich antigen blood group) and band 3 polymorphisms in two malaria holoendemic regions of Papua New Guinea. Am J Hematol 2004, 75: I-5.

58. Facer CA, Brown J: ABO blood groups and falciparum malaria. Trans R Soc Trop Med Hyg 1979, 73:599-600.

59. Martin SK, Miller LH, Hicks CU, David-West A, Ugbode C, Deane M. Frequency of blood group antigens in Nigerian children with falciparum malaria. Trans $R$ Soc Trop Med Hyg 1979, 73:216-218.

60. Mockenhaupt FP, Falusi AG, May J, Ademowo OG, Olumese PE, Meyer CG, Bienzle U: The contribution of alpha+-thalassaemia to anaemia in a Nigerian population exposed to intense malaria transmission. Trop Med Int Health 1999, 4:302-307.

61. Oppenheimer SJ, Hill AV, Gibson FD, Macfarlane SB, Moody JB, Pringle J: The interaction of alpha thalassaemia with malaria. Trans R Soc Trop Med Hyg 1987, 81:322-326.

62. Williams TN, Maitland K, Bennett S, Ganczakowski M, Peto TE, Newbold $\mathrm{Cl}$, Bowden DK, Weatherall DJ, Clegg JB: High incidence of malaria in alpha-thalassaemic children. Nature 1996, 383:522-525.

63. Bienzle U, Guggenmoos-Holzmann I, Luzzatto L: Plasmodium falciparum malaria and human red cells. I. A genetic and clinical study in children. Int J Epidemiol I981, 10:9-15.

64. O'Donnell A, Allen SJ, Mgone CS, Martinson JJ, Clegg JB, Weatherall $D$ J: Red cell morphology and malaria anaemia in children with Southeast-Asian ovalocytosis band 3 in Papua New Guinea. Br J Haematol 1998, I01:407-4I2.

65. Fowkes FJ, Imrie H, Migot-Nabias F, Michon P, Justice A, Deloron P, Luty AJ, Day KP: Association of haptoglobin levels with age, parasite density, and haptoglobin genotype in a malariaendemic area of Gabon. Am J Trop Med Hyg 2006, 74:26-30.

66. Snow RW, Marsh K: New insights into the epidemiology of malaria relevant for disease control. Br Med Bull 1998, 54:293-309.

67. Piper KP, Roberts DJ, Day KP: Plasmodium falciparum: analysis of the antibody specificity to the surface of the trophozoiteinfected erythrocyte. Exp Parasitol 1999, 91:161-169.

68. Askjaer N, Maxwell C, Chambo W, Staalsoe T, Nielsen M, Hviid L, Curtis C, Theander TG: Insecticide-treated bed nets reduce plasma antibody levels and limit the repertoire of antibodies to Plasmodium falciparum variant surface antigens. Clin Diagn Lab Immunol 200I, 8: I289-129I.

69. Gupta S, Trenholme K, Anderson RM, Day KP: Antigenic diversity and the transmission dynamics of Plasmodium falciparum. Science 1994, 263:961-963.

70. Cattani JA, Tulloch JL, Vrbova H, Jolley D, Gibson FD, Moir JS, Heywood PF, Alpers MP, Stevenson A, Clancy R: The epidemiology of malaria in a population surrounding Madang, Papua New Guinea. Am J Trop Med Hyg 1986, 35:3-15.

7I. Jarolim P, Palek J, Amato D, Hassan K, Sapak P, Nurse GT, Rubin HL, Zhai S, Sahr KE, Liu SC: Deletion in erythrocyte band 3 gene in malaria-resistant Southeast Asian ovalocytosis. Proc Natl Acad Sci USA |99|, 88: | 1022-11026.
72. Zhang L, Cui X, Schmitt K, Hubert R, Navidi W, Arnheim N: Whole genome amplification from a single cell: implications for genetic analysis. Proc Natl Acad Sci USA 1992, 89:5847-585I.

73. Cox MJ, Kum DE, Tavul L, Narara A, Raiko A, Baisor M, Alpers MP, Medley GF, Day KP: Dynamics of malaria parasitaemia associated with febrile illness in children from a rural area of Madang, Papua New Guinea. Trans R Soc Trop Med Hyg 1994, 88: $191-197$

74. Trager W, Jensen JB: Human malaria parasites in continuous culture. Science 1976, 193:673-675.

75. Day KP, Karamalis F, Thompson J, Barnes DA, Peterson C, Brown H, Brown GV, Kemp DI: Genes necessary for expression of a virulence determinant and for transmission of Plasmodium falciparum are located on a 0.3-megabase region of chromosome 9. Proc Natl Acad Sci USA 1993, 90:8292-8296.

76. Pasvol G, Wilson RJ, Smalley ME, Brown J: Separation of viable schizont-infected red cells of Plasmodium falciparum from human blood. Ann Trop Med Parasitol 1978, 72:87-88.

77. Vulliamy T, Luzzatto L, Hirono A, Beutler E: Hematologically important mutations: glucose-6-phosphate dehydrogenase. Blood Cells Mol Dis 1997, 23:302-313.

78. R Development Core Team: R: A Language and Environment for Statistical Computing. Vienna, Austria: R Foundation for Statistical Computing; 2005.

79. Kinyanjui SM, Mwangi T, Bull PC, Newbold Cl, Marsh K: Protection against clinical malaria by heterologous immunoglobulin $G$ antibodies against malaria-infected erythrocyte variant surface antigens requires interaction with asymptomatic infections. J Infect Dis 2004, 190: I527-1533.

80. Weatherall DJ, Clegg JB: The Thalassaemia Syndromes. 4th edition. Oxford: Blackwell Science; 200 I.

8I. Rowe JA, Obiero J, Marsh K, Raza A: Short report: Positive correlation between rosetting and parasitemia in Plasmodium falciparum clinical isolates. Am J Trop Med Hyg 2002, 66:458-460.

82. Cabrera G, Cot M, Migot-Nabias F, Kremsner PG, Deloron P, Luty AJ: The sickle cell trait is associated with enhanced immunoglobulin G antibody responses to Plasmodium falciparum variant surface antigens. J Infect Dis 2005, 191:1631-1638.

83. Verra F, Simpore J, Warimwe GM, Tetteh KK, Howard T, Osier FH, Bancone G, Avellino P, Blot I, Fegan G, et al.: Haemoglobin C and $S$ Role in Acquired Immunity against Plasmodium falciparum Malaria. PLoS ONE 2007, 2:e978.

Publish with Biomed Central and every scientist can read your work free of charge

"BioMed Central will be the most significant development for disseminating the results of biomedical research in our lifetime."

Sir Paul Nurse, Cancer Research UK

Your research papers will be:

- available free of charge to the entire biomedical community

- peer reviewed and published immediately upon acceptance

- cited in PubMed and archived on PubMed Central

- yours - you keep the copyright 